\title{
Spiritual discernment according to 1 Corinthians 2: the Spirit and discerning the wisdom of God (An exploration in Pauline discernment: part 1) ${ }^{1}$
}

\begin{abstract}
This paper investigates the nature of "discernment" as personally experienced and communicated by Paul regarding his discernment of the "wisdom of God" as revealed to him by the Spirit of God. It is the first part of two articles that explore Pauline discernment, specifically with reference to 1 Corinthians 2 . It is one of the main themes in 1 Corinthians 2 . The verb kpivw (decided, 2:2) and its derivatives

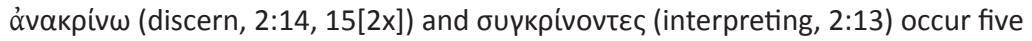
times in chapter two; this verb is used by Paul to explain how the spiritual person ( $\pi v \varepsilon \cup \mu \alpha \tau$ «ò) $)$ discerns the wisdom of God as this wisdom is mediated by the Spirit of God. This research endeavours to point out the coherence and relatedness of the different components that are involved in the process of the discerning of the wisdom of God.
\end{abstract}

\section{INTRODUCTION}

It is a great delight to offer this contribution to a fine and respected scholar. When reading the publications of Vincent Brümmer one becomes aware of his innovativeness. His ways of thinking is remarkable: this is sensible in the logic of his thinking and the constituents he raises in his discussions and arguments. The richness of his work and his confessions of faith, with which the author of this article can identify, is highly valued. This research focuses on "the Spirit and discerning the wisdom of God according to 1 Corinthians 2."

Paul's first epistle to the Corinthians is unique in the New Testament in that it shows the wide spectrum of problems encountered by one of the early church communities (Prime 2005:11). One of these problems seems to be that a high esteem for wisdom led to the creation of factions within this early church community. This is evident from the first four chapters which, together, form a unit. Paul addresses this problem indirectly by referring to another form of wisdom, one that will contradict the wisdom of the Corinthians. He opposes their human wisdom with divine wisdom, which is not accessible to everybody. This is evident in his statement: "And we speak of these things in words not taught by human wisdom but taught by the Spirit, interpreting spiritual

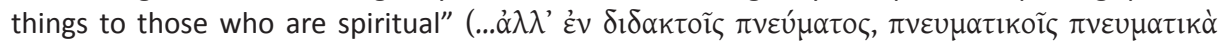

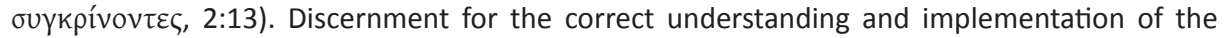
wisdom of God was a matter of great concern to Paul. ${ }^{2}$ In 1 Corinthians 2, Paul explains to the Corinthian congregation how the various components or phenomena that establish the discernment of this divine wisdom are knitted together.

In doing so, and when referring to the act of discernment, Paul uses the verb kpiv $\omega$ (decided,

1 This is the first article of two about "The discernment of the wisdom of God." The title of the second article is: Cognitive transformation and spiritual growth: the matrix for discerning the wisdom of God (An exploration in Pauline discernment: part 2).

2 See 1 Corinthians 1-4. 


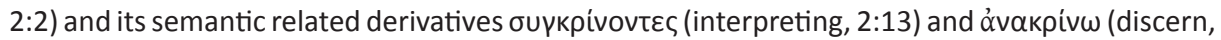

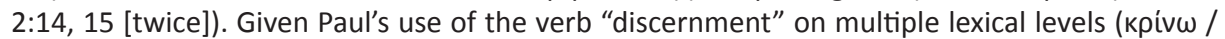

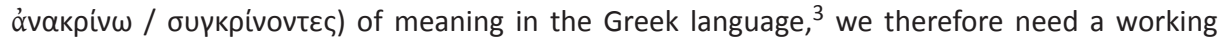
definition of the term "discernment". ${ }^{4}$ The following definition, as stated by Louw \& Nida (1996:363), will be used: "To make a judgment on the basis of careful and detailed information - 'to judge carefully, to evaluate carefully'."

With this working definition in mind, this article endeavours to point out, the relatedness and coherence ${ }^{5}$ of the different components that are involved in the process of discerning the wisdom of God (as explained in 1 Cor 2). In this article, I will also explain how Paul understood the process of spiritual discernment. This article will begin with a preview of the "literary context" of the selected text within the macro context of 1 Corinthians 1-4.

\section{LITERARY CONTEXT OF 1 CORINTHIANS 2}

Matters of literary context and the continuity of the argument are important in understanding I Corinthians 2 and, in particular, in understanding the nature and operation of spiritual "discernment" (cf. Cousar 1990:169).

The first four chapters of 1 Corinthians ${ }^{6}$ form an appropriate unit in the letter. The problems of factionalism or internal rivalries, ${ }^{7}$ which are specifically discussed in these chapters, are at the centre of the congregational difficulties that emerge as the epistle proceeds. The problem of divisions in the congregation, which revolves around various leaders in the congregation, is introduced as early as 1:10-17.

In this section Paul accuses the Corinthian church of $\sigma x i ́ \sigma \mu \alpha \tau \alpha$ (divisions, ${ }^{8} 1: 10$ ) and consequently makes several requests for unity. The facts regarding the divisions have been

3 See Herntrich (1979:921-933) and Büchsel (1979:933-954) for a thorough discussion on the verb

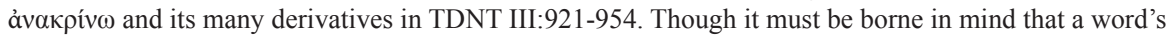
meaning can primarily be derived from its immediate literary context, though the macro textual context also plays a secondary role. One must be cautious to take one word and then build an entire theology around its lexical meaning.

4 Waaijman (2002:484) explains discernment as follows: "Diakrisis is the process of assembling and sorting out knowledge with respect to the way toward God. It tests the end and the means and creates a critical center. With a contemplative eye it looks at a person's life journey and envisions its perfection... Diakrisis is the critical-reflective moment of transformation in God." According to Danker (2000:66),

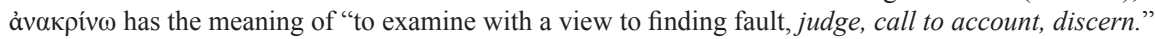
Louw \& Nida (1996:15) attach the following meanings to it: to study thoroughly (27.44); to investigate in court (56.12); to criticize (33.412) or to evaluate carefully (30.109). Later on (1996:363) they elaborate on the last proposal as "to make a judgment on the basis of careful and detailed information - 'to judge

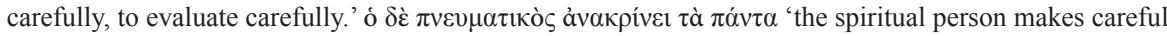

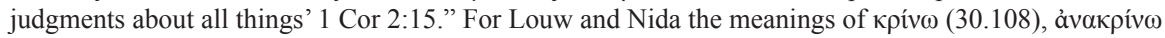

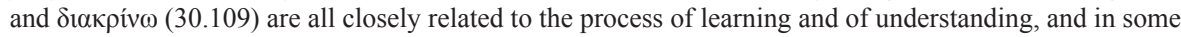
contexts the meanings shade one into the other. See also Herntrich's (1979:921) discussion of all the

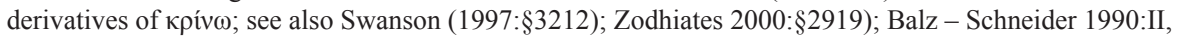
318).

5 Research on chapter 2 has not yet looked holistically into the discernment of divine wisdom. Past research on 1 Cor 2 focussed on individual aspects such as "wisdom" (Kaiser 1981:301-319; Baird 1959:425-432; Ellis 1974:82-98; Horsley 1977:224-239; Pogoloff 1992; Polhill 1983:325-339); “to know God” (Gärtner 1967-68:209-31; Gooch 1987); the "Holy Spirit" (Lim 1987:137-149).

6 There is general agreement that 1:10 to 4:21 constitutes an identifiable section (see Thiselton 2000:107).

7 See Garland 2003:37-39) for a discussion of different and nuanced views with regard to the nature of this conflict in the Corinthian church.

8 "Division, dissension, schism" (Danker 2000:981); "literally split, rift, division" (Friberg 2000:372). 


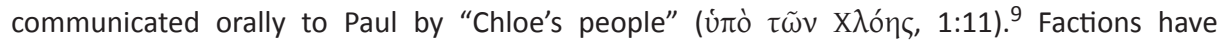
developed over certain figures of authority. Paul's response to this problem is not to favour one leader over or against another. Instead, he tries to make the community face the reality of schism (Cousar 1990:169). In his treatment of this situation he makes them aware of the joint

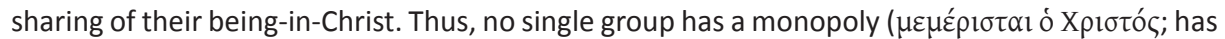
Christ been divided?, 1:13) (Thiselton 2000:107).

This introduction is followed by a discussion of the contrast between human and divine wisdom in 1:18-2:16 ${ }^{10}$ (Polhill:1983:325), an issue that is directly related to this factionalism. ${ }^{11}$ Paul tends to treat the problem of division as being symptomatic of a much deeper problem: the Corinthians' attraction to "the language of worldly wisdom" (Cousar 1990:169f). It is probable that some in the community understood themselves to be wise, and that these people regarded themselves as inspired, Spirit-filled persons (3:1) (Cousar 1990:170).

The key to Paul's interaction between these twin parallel themes of faction and wisdom is his conviction that the Spirit unites (see 1 Cor 12). Where the Spirit of God is present, there can be no internal rivalries, because it is the Spirit of God alone who reveals the divine wisdom (2:1012). Given this conviction, Paul does not discuss the ideas of the various Corinthian groups. For him, the existence of division proves that the various ideas found in the church at Corinth have their origins in human, rather than divine, wisdom (Polhill 1983:325).

This major subsection (1:18-2:16), which centres on the subject of wisdom, can be subdivided into smaller subsections. Verses 18-25 form the first subsection, where human-centred wisdom is contrasted with God's revealed wisdom. The fact that the wisdom of God contradicts human standards of wisdom is illustrated in the second subsection. In these verses, Paul points out that, firstly, God's calling of the Corinthians contradicted human expectations (1:26-31). Secondly, (2:15) Paul refers to his initial preaching to them in weakness, fear and trembling, and with simple speech; despite this, they came to faith through the power of God. The last contrast between human wisdom and the power of God (2:5) is developed in the third subsection (2:6-16), where Paul contrasts the discernment of spiritual people with the discernment of unspiritual people (cf. Garland 2003:39). ${ }^{12}$ In this subsection, Paul returns to the subject of the divine wisdom and its locus of revelation in the Spirit (Polhill 1983:328).

In 3:1-4, Paul characterises the Corinthians as being carnal rather than spiritual people. ${ }^{13}$ He refers to the party slogans ("I belong to Paul" and "I belong to Apollos") to prove that the Corinthians are carnal. He closes this subsection with three metaphors to describe the church: as God's field (3:5-9a), as God's building (3:9b-15), and as God's temple (3:16-17).

In 3:18-4:5, he reviews his argument about the foolishness of the wisdom of the world, which leads to foolish boasting about leaders. Paul summarises his argument in 4:6-13 and concludes in 4:14-21 with a fatherly admonition that they imitate him (4:16). The entire section (1:10-4:21) sets off and closes with the phrase "I exhort you" (П $\alpha \rho \alpha \kappa \alpha \lambda \tilde{\omega} \delta \dot{\varepsilon} \dot{u} \mu \tilde{\alpha} \varsigma . . . \Pi \alpha \rho \alpha \kappa \alpha \lambda \tilde{\omega}$ oưv $\dot{u} \mu \tilde{\alpha} \varsigma, 1: 10 ; 4: 16)$. Paul instructs them to bring their disputations under the rule of the cross in order to live in unity (Garland 2003:39).

9 On the reception of the oral report and criteria for reconstructing it, see especially Hurd (1983:47-50 and 61-94, esp. 82).

10 According to Stuhlmacher (1987:333) sets 2:6 (6a and 6b) the direction for a chiastic sequence: 2:7-9 expand on $6 \mathrm{~b}$ and $2: 10-16$ on $6 \mathrm{a}$.

11 This becomes sensible in 3:18-21 and 4:6-10 that the boasting of the Corinthians over various leaders involves a boasting of their own wisdom. Paul, himself, has also been charged by some members as lacking wisdom $(4: 1-5,8-21)$.

12 This contrast links the two subsections (2:1-5 and 6-16) with one another.

13 The occurrence of $\pi v \varepsilon v \mu \alpha \tau \imath k o ̀$, in both 2:6-16 and 3:1-4, links these two subsections. This linkage is

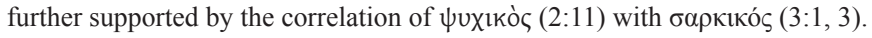


The above analysis creates the literary context and historical environment in which the rest of this paper has to be understood. Thus, the content of 1 Corinthians 2 revolves around wisdom and centres on the dichotomy between worldly wisdom and divine wisdom. Before we investigate the coherence of divine wisdom, and the role of the Spirit in the communication, understanding and discernment of this wisdom, we first need to examine how Paul communicated this wisdom to the Corinthian congregation.

\section{THE NATURE OF PAUL'S ROLE (2:1-5) IN THE WAY IN WHICH THE SPIRIT OF GOD COMMUNICATES THE WISDOM OF GOD (2:1-5)}

The subsection 2:1-5 forms a prelude for the main text (2:6-16); it is this main text that I will be examining in this article. In 2:1-5, Paul turns to his own preaching. ${ }^{14} \mathrm{He}$ recalls the point at which the discussion of the failure of human wisdom began (1:17). If he had communicated the gospel with sophistication, he says, the Corinthians might have been persuaded by his rhetoric and sophistry ${ }^{15}$ rather than by the Spirit of God. In these verses Paul explains how he avoided human wisdom and sophistication when he preached in Corinth.

First, he demonstrated no persuasive powers or rhetoric (2:4a) but preached only the message of the crucified Christ (2:2): ${ }^{16}$ "I did not come proclaiming to you in lofty words or wisdom ... (2:1). For I decided to know nothing among you except Jesus Christ ... (2:2). My speech and my proclamation were not with plausible words of wisdom (2:4a)." From these verses it is clear that Paul had decided to make Jesus the centre of his teaching when he preached at Corinth (Pratt 2000:25). This is why he did not come with "lofty words" (2:1) or "plausible words" (2:4) of wisdom. The choice of such a deliberate focus was based on his discernment and understanding of the gospel (cf. also Gal 1:15) and the needs of the Corinthian community.

Second, his style of preaching and physical presence among them were both characterised by weakness, fear, and trembling (2:3): "And I came to you in weakness and in fear and in much trembling." This suggests that Paul was an "anti-rhetor" (Hartman 1974:118). ${ }^{17}$ "Stripped of selfreliance" (the real danger, according to Fee 1987:96), Paul had to rely on the mercy and grace of

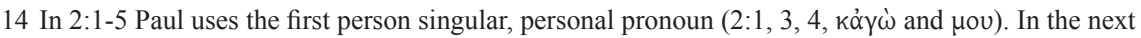
sub-section (2:6-16) "we" is the subject of the verb $\lambda \alpha \lambda$ oṽ $\mu \varepsilon v$, "we speak" (2:6). In fact, throughout this whole passage, Paul constantly employs to the first person plural pronoun "we" or "us" in vss. 10, 12, 13, and 16. Paul is probably referring to himself by this type of editorial "we" or "us", and perhaps in a derivative sense to those fellow-teachers who laboured with him. But in 1 Cor. 3:1 he switches back to the first person singular pronoun.

15 One might suppose, however, that Paul is rejecting the contemporary, sophist techniques as they were applied to preaching - a practice which emphasises the form rather than the content of the sermon and the role of the preacher rather than the Gospel (cf. I Cor. 4:20) (Lim 1987:149).

16 Theissen (1987:353) is of the opinion that Paul's rejection of persuasive words of wisdom in 2:4 might be an influence of the Jewish wisdom traditions on Paul's language.

17 Paul's comments about his weakness are not simply a rhetorical strategy as Pogoloff (1992:136) suggests, citing Quintilian (Inst. 4.1.8-10): "We shall derive some silent support from representing that we are weak, unprepared, and no match for the powerful talents arrayed against us" (cf. Dio Chrysostom, Or. 42.3). Paul's scriptural backdrop is more convincing (Snyder 1992:32; Thiselton 2000:220): Moses claimed a lack of eloquence (Exod. 4:10), Isaiah described himself as a man of "unclean lips" (Isa. 6:5), and Jeremiah protested that he was too young for public speaking (Jer. 1:6). In I Cor. 2:4, Paul is not rejecting rhetoric altogether, but specifically the Corinthian preachers' emphasis on and practice of employing human wisdom in preaching. For Paul, the preaching of the Gospel is not dependent upon any human techniques of persuasiveness, but upon the demonstration of the Spirit and power. This does not mean that devices and strategies of rhetoric are not to be used in preaching, but that they should be confined to their proper limits (Lim 1987:148). 
God, and how God could work powerfully through him (cf. Hartland 2003:86). ${ }^{18}$

Third, Paul avoided plausible words of wisdom in favour of "the demonstration of the Spirit and power of God" (2:4): "My speech and my proclamation were not with plausible words of wisdom, but with a demonstration of the Spirit and of power." With respect to his style of preaching (speech), as well as its content (proclamation), Paul intended that the ensuing faith of the Corinthians be grounded in the power of God and not in human wisdom (Cousar 1990:170). ${ }^{19}$ God's wisdom cannot be obtained through human wisdom. This is why Paul came to Corinth as a witness and not as a philosopher.

Paul's acknowledgement of his own human weakness makes it evident that, when he first preached at Corinth, he relied on the demonstration of the power of the Spirit. The fact that the Spirit manifested himself through Paul's preaching proved that his preaching did not lack power (Pratt 2000:26). In other words, Paul stresses his weakness in order to nullify the wisdom allegations of the Corinthians and to emphasise the role and the power involvement of the Spirit in his proclamation of the mystery of God (2:1).

He relied on the Spirit to convince the Corinthians so that their faith would not be based on the wisdom of any person (Greek culture relied on the worldly wisdom of philosophers and rhetoricians). Paul makes it clear that he feels that the Corinthian believers have begun to return to this cultural standard. In response, Paul points out that one of his primary goals is that the Corinthians build their lives on a new foundation, not on the wisdom of men (as in the case of Greek philosophers), but on the power of $\operatorname{God}^{20}$ (Pratt 2000:26; also Cousar 1990:170). This is why it is necessary to be able to discern the wisdom of God.

\section{THE WISDOM OF GOD (2:6-9)}

In 1 Corinthians 2:6,7 Paul states that "... among the mature we do speak wisdom ... we speak God's wisdom, secret and hidden, which God decreed before the ages for our glory". The term wisdom ( $\sigma \circ \phi i \alpha)$ appears in 1 Corinthians almost exclusively in 1:18-4:21, a section that has the literary form of an elaborate commentary or midrash. Here "the wisdom of this age" (3:19; cf. $1: 20 ; 2: 6)$ or "human wisdom" $(2: 5)$ is contrasted with "the wisdom of God" $(2: 7 ;$ cf. $1: 24,30)$ (Ellis 1974:87; also Baird 1959:425). ${ }^{21}$

In order to understand what Paul means in his reference to the "wisdom of God" we will look at the following three issues: the nature of God's wisdom, the content of this wisdom, and how this wisdom is received. These three issues explain why spiritual discernment of this wisdom is necessary.

\section{The nature of God's wisdom}

Nowhere in the long discussion of wisdom that begins at 1:18ff does Paul define what is meant by the "wisdom" that characterises the factions experienced at Corinth. ${ }^{22}$ Nor does he define

18 See Hartland (2003:85-86) for a good and thorough discussion on how other scholars have interpreted

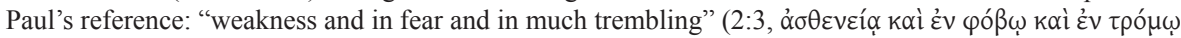
$\pi \circ \lambda \lambda \tilde{\omega}$ Ė $\gamma \varepsilon v o ́ \mu \eta v)$.

19 For Paul, the Kingdom of God is not manifested in words, but in power (I Cor. 4:20; cf. 2:5).

20 Note the strong adversative force of the preceding double $\delta \dot{\varepsilon} . . . \delta \dot{\varepsilon}$ ("On the contrary"), "Yet (2:6)... we

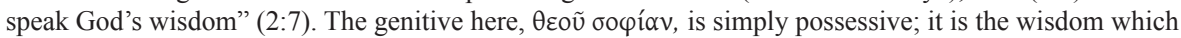

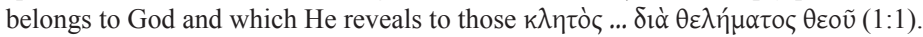

21 Cf. Wuellner, W. 1970. "Haggadic Homily Genre in I Corinthians 1-3,” JBL 89: 199-204.

22 For Grindheim (2002:689) Paul understood these factions as symptomatic of a theological error. For him, Paul's discourse on wisdom in 1 Cor 2:6-16 also serves his rhetorical purpose of undermining the basis of the various factions (2002:690). Pogoloff (1992:104) differs from Grindham. According to him: 
the content of the wisdom for the mature in 2:6ff. This is because it is not Paul's intention to do so: it would sidetrack his whole argument. His entire purpose is to bring the Corinthians back to the only wisdom that counts - the wisdom of the cross. ${ }^{23}$ This wisdom of God (2:7), coming from the Spirit (2:10-12), will now be examined more closely:

Firstly, this wisdom, which forms the essence of Paul's message, is a secret conceived by God Himself. Until He unveiled it to Paul, this wisdom was known only to God; God's wisdom "is a

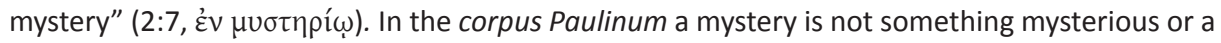
truth that humans cannot comprehend. ${ }^{24}$ Instead, according to Kaiser (1981:312), it is a truth or fact which human understanding cannot discover by itself, but which one can adequately grasp once God has revealed it to his prophets or apostles. ${ }^{25}$

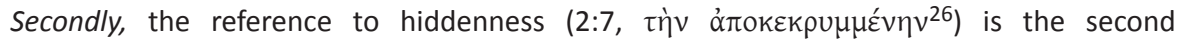
characteristic of this wisdom. God was pleased to be silent about this wisdom for long ages, until the time came for Him to reveal it (cf. Rom. 16:25). God's wisdom was therefore a mystery in the biblical sense of that word and was long hidden before God chose to disclose it (cf. Kaiser 1981:312).

The third feature of this unique wisdom was that it was "marked out" or "decreed" (2:7) long ago before the ages in the eternal plan of God. Paul's wisdom was not thoughtless or subjective (Kaiser 1981:312) conjecture and nor was it a series of scholarly pastoral homilies on certain religious topics. God had planned for its release long before the ages came into existence for

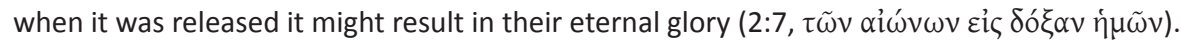

A fourth characteristic of this wisdom is that none of this world's rulers ${ }^{27}$ understood it $(2: 8) .{ }^{28}$ Indeed, in their ignorance of this wisdom, they crucified the "Lord of glory". This wisdom was superior to all human thought or the thought of any individual person, and was superior to any wisdom the leaders of this world might possess.

In three more related clauses, Paul continues to describe this wisdom. ${ }^{29}$ It does not originate

"Paul is addressing an exigence of the ethical dimensions of division, not doctrinal divergence." Dunn (1995:43) mentions the scholarly neglect of the theological dimension of the conflict.

23 Only the Spirit of God apprehends the plans and purposes of God, and only this Spirit can link God and humans together (Gärtner 1967-68:218). What God is doing, only God knows (Garland 2003:99). Gooch (1987: 36) explains what Paul means: "It is not simply that just as individuals have private thoughts not known to others, God has private thoughts too, rather, if human things are known only to human knowers, divine things are known only to God's Spirit." Paul's intention "is to draw a thick and heavy line between things human and divine and to place the things of God squarely outside the limits of human knowing" (Garland 2003:99).

24 See Brummer (2005:4f) for a thorough discussion on this point of view.

25 See Paul's definition of $\mu v \sigma \tau \eta$ pí $\omega$ in Rom 16:25.

26 "to keep from being known, keep secret" (Danker 2000:114); "keep secret" (Louw and Nida 1996: $\$ 28.80)$.

27 Cousar (1990:171) interpreted "Rulers of this age" as political and religious figures or as apocalyptic powers. In his article on "the rulers of this age", Miller (1972:522-528) convincingly argued that, in 1 Cor 2:6-8, they "are to be understood as a reference to human, earthly authorities, and not to supernatural or spiritual, demonic or angelic powers." They trusted in their own "human wisdom" and plans and consequently knew nothing of the "wisdom of God". Gaffin (1987:110) added to this: "The rulers of this age are representative; in them we see the most impressive achievements of the present world-order, measured by the standards of human rebellion and unbelief; within the creation, as presently subject to the curse on sin (cf. Rom 8:18-22), they exemplify the most that it has to offer and is capable of attaining."

28 Brümmer (2005:4) points out that "Although believers would admit that Jesus "suffered for our salvation" the way in which this is usually explained seems highly problematical." He states that if such fundamental doctrines involve logical and moral condundrums, how then can Christians be required to believe doctrines which they cannot understand?

29 In this verse Paul is not trying to point out what he is speaking among the spiritual (mature) but to 
from empirical sources, traditional knowledge in the community, or from intuitive insight or imagination. With these references Paul has shattered every conceivable earthly source for these words of wisdom which he announces. Consequently, this wisdom could only emanate from God. What Paul is claiming is quite clear: this wisdom is a revelation, a disclosure of the divine mind by the Spirit to the Apostle, a human being.

An eighth characteristic of this wisdom is that the wisdom of God is different from human wisdom in two ways. (1) Since it is "hidden", it is comprehended neither by natural man and his wisdom (2:13f.; cf. 1:21) nor by the wicked "rulers of this age" (2:8) under whose influence natural man and his wisdom ultimately stand. (2) Since it is "wisdom among the mature", it presupposes, as 1 Corinthians 3:1-3 makes clear, not only understanding but also the ethical fruit of the Spirit, a mind that is being renewed to do the will of God (cf. Rom. 12:2).

The last characteristic is that this wisdom concerns God's plan of salvation, "a wisdom foreordained for our glorification"30 (2:7) and the "things God has prepared for those who love him" (2:9). It was disclosed (taught, $\delta 1 \delta \alpha \kappa \tau o i \varsigma)$ by the Spirit ( $\pi v \varepsilon u ́ \mu \alpha \tau o \varsigma)$ "who interpret

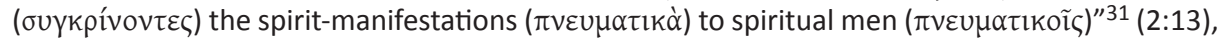
"so that we may know ( $\varepsilon i \delta \tilde{\omega} \mu \varepsilon v)$ the things given to us by God" $(2: 12)$.

\section{Content of the wisdom ${ }^{32}$}

In the first two chapters of 1 Corinthians, Paul refers to and discusses the "wisdom" concept from various perspectives:

\section{Antithetical statements}

In the first two chapters, a series of antithetical statements ${ }^{33}$ is set over against one another. In

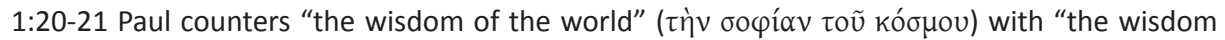

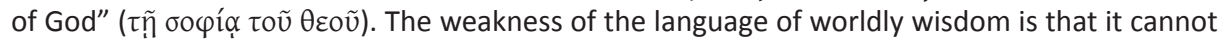
enable the world to know God (1:21); it cannot bring God to discourse. Instead, Paul argues that the preaching of the crucified Messiah, understandably foolish to the eyes of the world, becomes the instrument whereby God proves the wisdom of the wise ${ }^{34}$ to be wrong (Cousar 1990:170). The gospel of the cross appears as foolishness for those who are lost, but antithetically proves to be the power of God for those who are saved (2:18). This double character of the word of the cross is then delineated in the following verses, so that the "foolish" character is elaborated on in

demonstrate "the nature of that wisdom to be sublime and inaccessible to man" (Kaizer 1981:313).

30 Schrage (1991: 1:251-52) stresses the eschatological character of $\delta o ́ \xi \alpha v \dot{\eta} \mu \tilde{\omega} v$ (our glory) here: he compares it with $\pi \rho \dot{\tau} \tau \tilde{\omega} v \alpha i \omega ́ v \omega v$ (before the ages) as the Urzeit-Endzeit pattern of soteriology, i.e., the final end-time goal at last corresponds to the original point of departure or "primal time" of apocalyptic. According to Kistemaker \& Hendriksen (2001:81f), Paul refers here to "hidden wisdom, which God predestined before all time for our glory". Wisdom that has been hidden until Paul's present time is now revealed through the person and work of Christ. See also Pratt (2000:34); Thiselton (2000:242).

31 Also translated "... in a spiritual way..." This possibility will become clearer later on in this article.

32 Horsley (1977:224) has pointed out that "scholarly investigation has concentrated primarily on sophia as the means and content of salvation, searching for its background in Jewish wisdom speculation or a Gnostic Sophia-myth".

$33 \mathrm{Cf}$. the antithesis that has been prominent all the way since 1:18 between the believers and those who are lost: "those who are saved" vs. "those who are lost" (1:18); "those who believe" vs. "Jews demand signs and Greeks desire wisdom" (1:21-22); "those who are called" vs. "the wise" (1:24, 27); "the perfect" vs. "the rulers" (2:6); "for our glory" vs. "those who perish" (2:7, 6); "to us God has revealed" vs. "none of the rulers of this world knew" $(2: 10,8)$; "those who love him" vs. "they crucified the lord of glory" (2:9, $8)$; "the Spirit that is from God" vs. "the spirit of the world" (2:12); "spiritual" vs. "natural human being" $(2: 15,14)$; "the mind of Christ" vs. "foolishness for them" $(2: 16,14)$ (Du Plessis 1959:179).

34 This identification in 1:24 and 30 becomes critical in 2:6-13. 
1:19-2:5 and the "powerful" or "wise" character in 2:6-3:23. ${ }^{35}$ In 1:19-31 Paul explains how God has overturned the values of the world (Mitchell 1991:87). That which is considered wise in the world is foolishness to God, and vice versa (1:21, 25; cf. 2:14) (Grindheim 2002:692).

\section{Incomprehensible to the world}

According to Cousar (1990:171) 2:8 is the key for understanding the content of this wisdom. The rulers of this age demonstrated their ignorance of divine wisdom when they "crucified the Lord of glory". Paul's reference to the "crucifixion of the Lord" shows the argument very much in continuity with the preceding section and reminds us that the wisdom of God, which is incomprehensible to the world, is nothing other than the proclamation of the cross (1:23-24). It is spoken of as "secret" and "hidden" because it is rejected by both Jews and non-Jews as being scandalous. However, the "spiritual man"36 among whom God's wisdom is disclosed and grasped are none other than "those who are called", those for whom the crucified Christ is the wisdom and power of God (1:24) (cf. Rhyne 1990:175).

\section{The crucified Christ}

Paul explains how he avoided human wisdom and sophistication when he preached in Corinth (2:1-5). He says that he had determined to "know nothing ... except Jesus Christ." Hence, the content of his preaching at Corinth was exclusively that of the crucified Christ (2:2) (cf. Polhill 1983:331; also Schnelle 2005:202f.). The crucifixion as the way of salvation was the most offensive dimension of the gospel. It opposed the human arrogance of both Jews and Gentiles. Nevertheless, it was the power of God for salvation (Pratt 2000:25). Baird, writing significantly earlier than Polhill and Schnelle, adds a new dimension to the meaning and understanding of this wisdom. According to him (1959:425-432), this wisdom involves more than the bare fact of the crucifixion and the simple doctrine that Christ died. ${ }^{37} \mathrm{He}$ is correct in stating that "to know nothing but Christ and him crucified" does not imply a limitation of knowledge; instead, it involves understanding the whole purpose of God's creation and redemption. The wisdom of God is manifest in the proclamation of the crucified Christ who is the revelation and consummation of God's whole drama of salvation (Baird 1959:431-2).

We must take care not to read a narrow, one-sided theology of the cross out of (or into) $2: 2,8$. It has to be connected with the equally aphoristic assertion to be found in 2 Tim 2:8: "Remember Jesus Christ raised from the dead,... according to my gospel." The centre of Paul's gospel is Christ's death and resurrection in their significance as the fulfilment of Scripture (1 Cor 15:34). Here it entails ultimately the soteriological-eschatological renewal of nothing less than the entire creation (2 Cor 5:17) (Gaffin 1995:108). God's eschatological wisdom, focused in Christ's cross and resurrection, is still in view here, and elaborates on Jesus' kingdom vision in Matthew 11/Luke 10 (Gaffin 1995:115)

\section{Conclusion}

The most likely conclusion, therefore, is that the wisdom, which is spoken in a mystery, is the

35 Theissen (1987:345) observes the parallel structure between 1:18-2:5 and 2:6-3:23. The section 1:182:5 he counts under the heading "The preaching as foolishness," and 2:6-3:23 under "The preaching as wisdom," finding parallel subsections in 1:18-25 ("The word of the cross as foolishness in the world") and 2:6-16 ("The preaching as wisdom among the perfect"); 1:26-30 and 3:1-4 ("Application to the community"); 2:1-5 ("Application to the apostle") and 3:5-23 ("Application to the apostles").

36 Those who appropriate this wisdom are repeatedly designated with a dative. This sets them apart as an elect group ("saved" in 1:18, "called" in 1:24, and "perfect" in 2:6) (Grindheim 2002:695).

37 Kaiser (1981:314) agrees that the "deep things of God" must include God's essence, attributes, and plan. 
message of the death of Christ, or more comprehensively, the gospel regarding Christ (cf. 1:17a; Rom 1:16) (Stuhlmacher 1987:334; also Fee 1987:227, 250-251). This interpretation gains further

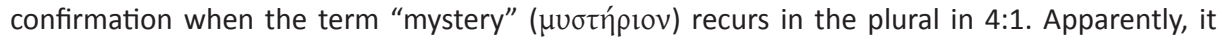
seems to be a reference to the gospel or God's plan of salvation (Grindheim 2002:696; also Barrett 1992:100; Fee 1987:160).

\section{How the Wisdom was received}

Paul describes the revelation and reception of wisdom ${ }^{38}$ from various perspectives, all of which complement each other:

1. "...these things God has revealed ( $\alpha \pi \varepsilon \kappa \alpha ́ \lambda v \psi \varepsilon v)$ to us through the Spirit..." (2:10);

2. "...taught ( $\delta$ i $\delta \alpha \kappa \tau o \tilde{c} \varsigma)$ by the Spirit..." (2:13);

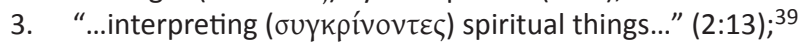

4. "...may understand (oĩ $\delta \alpha)$ the gifts bestowed on us by God" (2:12);

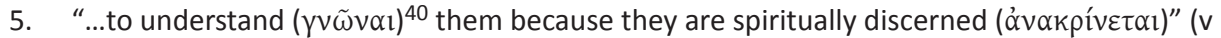
14).

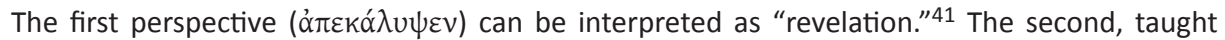

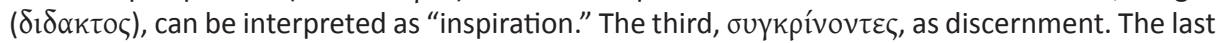
two related verbs (oĩ $\delta \alpha$ and $\gamma v \tilde{\omega} v \alpha \mathrm{L}$ ) are used to indicate understanding and can be interpreted as the "illumination of Scripture". Although different verbs have been used by Paul, they are all connected semantically in order to constitute "comprehension". The sequence of these verbs in the text also shows a logical progression in the process of discernment: reveal - teach - interpret - understand.

\section{The process of discernment}

Revelation: Reveal

Inspiration: Teach

Interpretation: Interpret

Illumination: understand

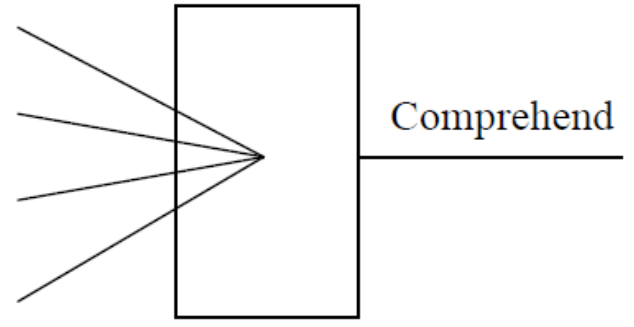

38 When Waaijman (2002:582) discusses the analysis of Aristotle's practical wisdom, he draws attention for the need for wisdom to discern all possibilities in a specific concrete situation and consequently to orient everything to the end. With Paul, spiritual discernment is needed to discern the wisdom of God.

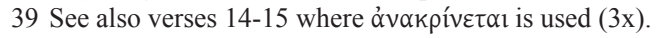

40 The text (2:14) uses "understand" in a negative sense, referring to the natural man who "does not receive the gifts of God's Spirit" and consequently cannot understand the spiritual things.

41 Cf. Kaiser (1981:314) who initiated the idea of "revelation" and "inspiration" in these texts. 
Revelation $^{42}(2: 10-12)$

Three expressions describe the knowledge given by the Spirit of God to Christians: "the depths of God" (2:10), "the thoughts of God" (2:11), and "the gifts bestowed on us by God" (2:12). ${ }^{43}$

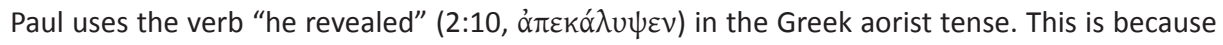
Paul has in mind a definite point of time in the past when God made known to him this wisdom by way of a revelation. ${ }^{44}$ This experience was unique to the biblical authors (Kaiser 1981:314). ${ }^{45}$

The revelation which Paul claims for himself in I Corinthians 2:10-12, concerns the disclosure

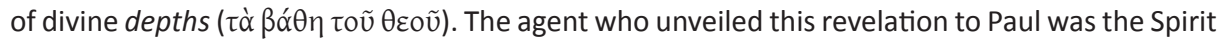
of God. Indeed, the "deep things of God" must refer to God's detailed plan for salvation ${ }^{46}$ (cf.

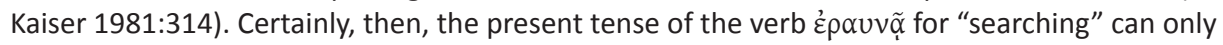
refer to the unceasing activity of the Spirit. Here it relates to the intra-Divine activity as the Spirit of God fulfils the task of revealing the deep things of God to Paul.

God takes the initiative (see also Ephesians 1:3-14) and, through human instruments such as Paul $(\lambda \alpha \lambda$ oũ $\mu \varepsilon v, 2: 7,13)$, He reveals his secret and hidden wisdom. Operating in and with the preaching of the cross, the Spirit unravels the web in which "worldly wisdom" has caught people. They are brought into a world constituted by the language of crucifixion, where God's wisdom, God's power, and God's righteousness are understood in rather unusual ways.

42 For Gaffin (1995:105), what has been revealed is beyond all human capacity and competence, whether rational or intuitive; it is inaccessible to human potential in its highest actualisations. The necessity of

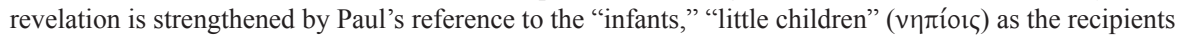
of revelation, in counterpoint to the "mature".

43 Gaffin (1995:105f) convincingly uses Luke 10:21-22 as the point of departure to define the scope of revelation. Here in Luke 10 revelation is designated as "these things" ( $\tau \alpha \tilde{v} \tau \alpha, \mathrm{v} 21)$ and "all things" ( $\pi \alpha ́ v \tau \alpha, v 22$ ). It is part of Jesus' teaching about the eschatological "kingdom of God". More specifically, the kingdom is a matter of the eschatological lordship of God in Jesus, the Christ, presently being realised in his arrival and to be consummated fully at his return.

Consequently, "these things", as the content of revelation, are to be considered comprehensively. They are in fact "all things" (v. 22), that is, all that has its origin in the unique fellowship of knowledge between Father and Son, and is purposed by them for revelation in and by the Son (v. 22). Or, as already noted, "these things" are all that is revealed and brought to realisation in the coming of the kingdom. It might appear that this kingdom-qualification somehow limits the scope of "all things". But, to the contrary according to the NT, there is nothing in the entire creation that is irrelevant to the kingdom; absolutely nothing falls outside the eschatological rule of Christ. For Gaffin (1995:107) the kingdom of God is totalitarian in the most ultimate sense we can know and experience. It is not partial. There is no area or dimension of human knowledge that lies outside the scope of the revelation in view in these verses, or for which that revelation is irrelevant. Any epistemological endeavor true to these verses recognises its absolute, exclusive dependence on such revelation.

44 Cf. Galatians 1:11, 12, 17. Paul writes this entire pericope to prove that his teaching was not influenced by anyone - he received the Gospel that he preaches directly from God. God is his witness about this.

45 While it is true that Paul also uses the same root of the word to say that God has given a revelation to

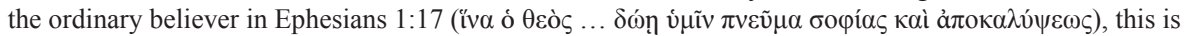
only a secondary and derivative revelation (see Kaiser 1981:314).

46 According to Schweizer (1968:426): "The content of the supernatural knowledge is not disclosure of mysteries of the heavenly world but the divine act of love effected at the cross, or the divine sonship granted to the believer thereby." Garland (2003:98) agrees with Schweizer that the supernatural knowledge refers the depths of God to what God has foreordained (2:7) and prepared (2:9), the divine plan for human redemption (cf. Rom. 11:33). Wolff (1996: 58-59) notes that the word "depths" is at home in the apocalyptic literature (1 Enoch 63:3; 2 Bar. 14:8-9; T. Job 37:6; 1QS 11:18-19). The term's appearance in later Gnostic literature has no bearing on Paul's usage. Kaiser (1981:314) differs from Schweizer and Garland. For him "the deep things of God" includes his nature, attributes and plan. 


\section{Inspiration (2:13)}

Paul (and the other apostles) do not speak an ordinary, natural message. His teaching is not human invention; instead, Paul is "taught $(\delta 1 \delta \alpha \kappa \tau o \zeta)$ by the Spirit." ${ }^{7}$ Paul's main idea is evident. The Holy Spirit's revelation was very special and cannot be discerned or communicated by ordinary means. For Kaiser (1981:314ff) this verse is probably the most precise statement on the mode of inspiration. According to Kaiser, it refers to the connection and method by which the divine Spirit and the human author interacted in the transmission and recording of these "deep things of God".

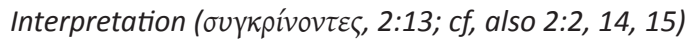

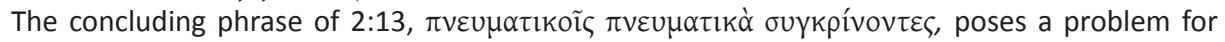
interpretation (Gardner 1994:138). ${ }^{48}$ The gender of $\pi v \varepsilon \cup \mu \alpha \tau$ เкоĩ, however, could be masculine or neuter, and the verb биүкрíveıv could mean "interpret," "compare," or "combine" (Garland 2003:99; also Büchsel 1979:954). If the noun is taken as masculine, Paul could mean that he, by the Spirit, teaches the things of God and interprets spiritual truths to spiritual people (Rhyne 1990:175). If the noun is taken as neuter (see $p$ 13), however, Paul means that he marries spiritual truths to spiritual expression (Kaiser 1981:317; Pratt 2000:37). According to the entire context (2:6-3:5) it is not an "either ... or", but rather a case of "complementing". Both meanings are equally true and present in this text and can be interpreted as: "spiritual truths ( $\pi v \varepsilon v \mu \alpha \tau ı k \alpha$ ) come through spiritual expression taught by the Spirit who expresses these spiritual truths to spiritual people". 49

\section{Illumination of Scripture (2:14-16)}

The work of the Spirit of God, in applying the truths Paul has received from God, is clearly distinguished here. 1 Cor. 2:14 continues: "Neither can the natural man know ( $\gamma v \tilde{\omega} v \alpha)^{50}$ the things of God, because they are Spiritually discerned" (see also Gaffin 1995:114). ${ }^{51}$ If a distinction

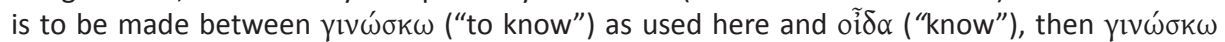
is not merely perceiving things, but "embracing things as they really are". 52 Thus, the natural man neither welcomes nor embraces the realities found in the biblical text because they are

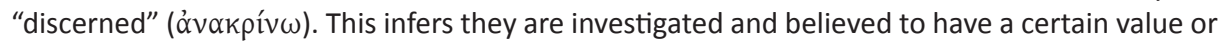
worth by a person who is aided by the illuminating work of the Spirit. Now the Spirit's ministry, as far as discernment is concerned, is one of aiding the believer to apply, to see the value, worth, and significance of a text for his own person, situation, and times (Kaiser 1981:318). To know

47 Paul's statement in 2:13 recalls what he argues in 2:4. His preaching "was not with the persuasiveness of wisdom but with the demonstration of the Spirit and power".

48 This last part of the verse is stylistically quite heavy in the Greek. Its meaning is not entirely clear. Part of its reasoning may be that Paul is piling up words ( $\pi v \varepsilon v \mu \alpha \tau$ several repetitions, in order to emphasise his main argument (Ellingworth-Hatton 1995:59).

$49 \mathrm{Cf}$, "How the wisdom was received" (p 13).

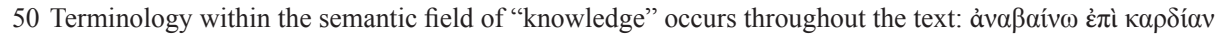

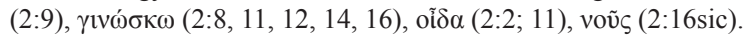

51 Brummer's (1981:153) thoughts on "believing and understanding" help to understand the statement made by Paul in 1 Corinthians 2:14. According to him "It is possible to understand a statement without believing it." It is only when a person understands the stating of someone that he / she can accept the proposition of that person as true or reject it as false. In this sense understanding is a precondition for both believing and disbelieving. Brummer (2006:162) is correct that believing is then more than merely understanding; "it is understanding and accepting as true."

52 The contrast between $\gamma \mathbf{v} \omega \dot{\sigma} \sigma \omega \omega$ and oĩ $\delta \alpha$, is that the first often suggests an acquired knowledge, but oí $\delta \alpha$ suggests intuitive knowledge (Zodhiates 2000). It needs an obj. gen., and in the first instance denotes the act of knowing rather than knowledge (Bultmann 1979:690). 
God turns out not to be an intellectual exercise in which the minds of Christians are attuned by the Spirit to be more sensitive to divine things than they otherwise might be. Instead, it entails the simple but critical discovery that they are people who live by grace and from grace (cf. Cousar 1990:173). ${ }^{53}$ The "illumination of the understanding in the light of faith" leads, according to Brümmer (2008:152), to the inspiration of the heart. It also renews life in the fellowship of God.

To summarise: we need to know the nature of the wisdom of God, its contents and how it is received before we can understand why special discernment of this wisdom is required. Through the high frequency of occurrence of the word spiritual in this context (2:10,13-15), Paul points out that the wisdom which he had brought to the Corinthians was from the Spirit of God and taught by the Spirit alone. It can neither be learned nor be communicated by human wisdom, as the Corinthians believed (Pratt 2000:37).

\section{THE SPIRIT AND THE RECEPTION OF THE WISDOM OF GOD (2:10-13A)}

In his discussion about receiving the true wisdom of God, Paul gives the Christian reader insight into the character of the Spirit Who is responsible for conveying the divine wisdom to believers. The identity and nature of the Spirit is such that only the Spirit can communicate the wisdom of God. In the selected text (1 Cor 2) there are explicit references about the Spirit regarding His relationship with and affinity to God. In 1 Cor 2 Paul clearly states that the Spirit is "the Spirit of God" (2:11, 12, 14), He "searches everything", "even the depths of God" (2:10); and "comprehends what is truly God" (2:11). Paul describes the role of the Spirit as being to reveal the wisdom of God $(2: 10)$; He bestow gifts $(2: 12,14)$ on believers; makes understanding possible (2:12); and He also teaches (2:13).

\section{The Spirit's relationship and affinity with God}

The wisdom that is communicated to the spiritual man is not human reflection on the gospel but, like the gospel itself, only comes as revelation, as a divine gift.

The agent of the revelation of the wisdom of God is the Spirit who is the Spirit of God (tò

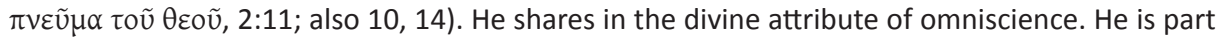
of God's council.

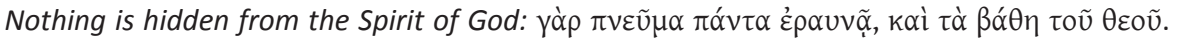
Although an infinite number of things about God will always remain hidden from the human mind, God's hidden thoughts are evident to the Spirit of God (Pratt 2000:36) because He "searches everything, even the depths of God" (2:10). Only He knows what is truly God. To lend support to his assertion, Paul draws up an analogy between the human spirit and the Spirit of God (2:11). He begins by acknowledging that many things about a person's thoughts remain hidden to other people. So it is with the Spirit of God: He alone comprehends what is truly God, and only He knows the depths of God.

Human beings cannot see into the mind of God "from the outside", as it were, using human wisdom. Only the Spirit of God knows the thoughts of God because He searches "the depths of God", 54 the innermost reality, and only He can disclose those hidden things to the spiritual man

53 Schmitz (1976:400) adds a new perspective. For him the knowledge ( $\gamma \bullet \omega \dot{\sigma} \sigma \kappa \omega)$ of God $(2: 11,14)$ comes about through the acceptance of salvation in the forgiveness of sin. Therefore, it can be nothing other than the gift of God (see Lk 1:7). This knowledge, according to him (1976:403) includes knowledge of the One he has sent. This illumination relates with Brümmer's (2008:149f) perception of "religious experience" which he defines as ".. ordinary experience (including ordinary sense perception) looked upon with the eyes of faith." For him "religious experience" then becomes "'hermeneutical' in the sense that it entails an interpretation of our ordinary experience ..."

54 The depths of God refer to what God has foreordained (2:7) and prepared (2:9) - the divine plan for 
(Pratt 2000:36; also Schlier 1979:517). A deeper understanding of this is first made possible and accessible for the Christian by the Spirit of God (2:10) (Delling 1978:657). The associated activity ascribed in 2:10 to the Spirit of God, by means of the verb દ́pauvá $\omega$, does not mean searching in order to discover something, but the activity of exploring God's purposes thoroughly in order to reveal them (Schrage 1991:257f). The idea that Paul tries to communicate here is "to search out" and not "to search" (Thiselton 2000:257).

\section{The role which the Spirit plays}

Verses 2:10-16 bring out the comprehensive role of the Spirit in the revelation process. He initiates both the giving and receiving of revelation; the Spirit knows and the Spirit communicates. Verses 10-11 address the former. The functioning of the Spirit in the revelation process proves his requisite investigative competence. He alone has the ability to comprehensively search out $(\varepsilon \cos (\varphi)$ ) "all things", including "even the deep things of God". (Gaffin 1995:112). It is the Spirit, therefore, Who reveals the wisdom of $\operatorname{God}(2: 10)$; He bestows gifts $(2: 12,14)$ on believers; makes understanding possible (2:12); and also teaches (2:13). This wisdom is not human reflection on the gospel but, like the gospel itself, only comes as revelation, as a divine gift. Those who are in Christ have received the Spirit and thus are receptive to its revelation (2:12). It is through the Spirit that Paul teaches and proclaims (2:1) the "mystery of God", and only those enlightened by the same Spirit are able to understand Paul's teaching (2:13).

The Spirit's role in communicating the message of the gospel raises an important issue for Paul. The message about which Paul and the apostles speak is not an ordinary, human message. Indeed, human wisdom (i.e., eloquent human reasoning) cannot find the words to express the message. Instead, this message is conveyed through words taught by the Spirit who expresses spiritual truths in spiritual words to spiritual persons (2:13). Only those who are under the influence of the Spirit of God can receive Christian instruction. ${ }^{55}$ It cannot be learned or communicated by human wisdom, as the Corinthians incorrectly believed. People without the Spirit are not able to accept the things that come from the Spirit (Pratt 2000:37). In fact, the Christian message appears as foolishness to those who lack the Spirit (2:14).

\section{Conclusion}

In 2:10-13 Paul explains how the Holy Spirit imparts divine wisdom to those who are spiritual. In his argument, Paul undermines the Corinthians' claim to spirituality - another source of their pride and divisiveness. True spirituality would not have led them to adopt any form of human wisdom. To be truly spiritual, they will have to turn from human wisdom to the divine wisdom of the gospel (cf. Pratt 2000:36). The Spirit makes discernment possible, but only to those who are spiritual.

\section{THE DISCERNMENT OF THE WISDOM OF GOD (2:14-16)}

From what has been said so far it is evident that, for the comprehension of "divine wisdom,"

human redemption (cf. Rom. 11:33). I agree with Schweizer (1968:426): "The content of the supernatural knowledge is not disclosure of mysteries of the heavenly world but the divine act of love effected at the cross, or the divine sonship granted to the believer thereby" (Garland 2003:98). Schlier (1979:517) defines it as "'depth' or 'depths' figuratively in many different senses, mostly to denote the inscrutability or hiddenness as well as the vastness or greatness of something". See Thiselton 2000:257ff) for a

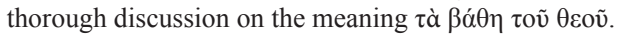

55 Brümmer (2008:147) correctly states that the Spirit of God opens the eyes to discern the acts of God. The Spirit inspires the hearts but also illuminates the understanding. Only the eyes of faith can see Jesus as the Son of God in whom the forgiving love of God is manifested. 
as revealed by the "Spirit of God", special discernment is needed - something that can only be given to a spiritual person by the Spirit of God. Paul, who can be regarded as a spiritually mature man (cf. 2:4; 3:1,2), writes as follows in 2:2: "For I decided (Ěkplvó) to know nothing among you except Jesus Christ, and him crucified." Superficially, (cf. 2:1-5), Paul appears to be an antiintellectual. In fact, however, this is hardly the case, for we know that he received lengthy and intensive training in Jerusalem and Tarsus. Moreover, Paul was acquainted with the Greek quest for knowledge and wisdom (Acts 17:17). That said, he was not in the slightest bit interested in teaching the Corinthians the various methodologies which the Athenian thinkers had adopted and which humanistic philosophers of the day promoted. Instead, Paul makes it clear that he came to preach the gospel about the crucified Christ (1:23; Gal. 6:14) (Kistemaker \& Hendriksen 2001:73).

Unlike some members of the church community at Corinth, who were eager to tell everyone how much they knew, Paul wants to limit his claim to knowledge; he knows only Christ the crucified - this is all he wants to communicate to them (Ellingworth \& Hatton 1995:45f). Paul's use

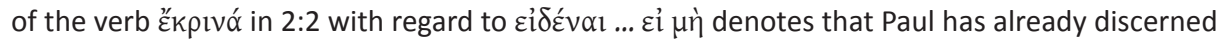
that the "gospel" is the centre of the wisdom that the Spirit of God has revealed to him.

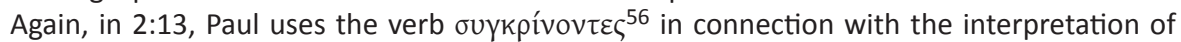
spiritual things by those who are spiritual. ${ }^{57}$ As already spelled out in section 4.3 this verb can be interpreted as: "spiritual truths ( $\pi v \varepsilon v \mu \alpha \tau \imath k \alpha$ ) came through spiritual expression taught by the

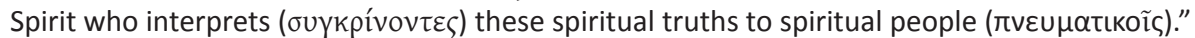

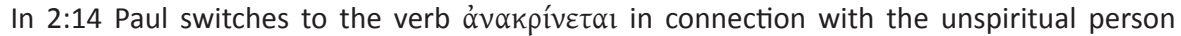
who is unable to discern spiritual things. In 2:15 he uses óvokpível ${ }^{58}$ again, now with regard

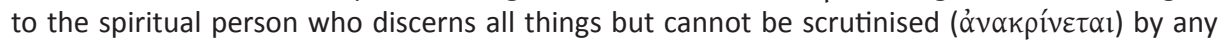
unspiritual person. These three actions are closely related. The first two form a dichotomy, while the last one is consequential (because of the dichotomy). In 2:14-16a, Paul explains why divine

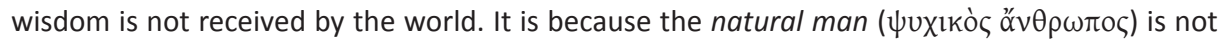
a reference to the weak Christian, but represents natural, physical existence that is dependent on human faculties without the aid of the Holy Spirit. According to Paul, such a person does not receive any gifts of the Spirit of God and is unable to understand (discern) them "because they

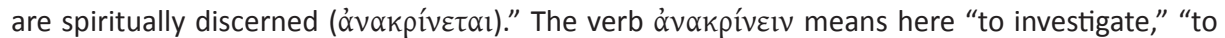
examine" (cf. 1 Cor. 10:25, 27). ${ }^{59}$ The natural person analyses divine truth with his or her limited, earthbound talents and, not surprisingly, finds this truth inadequate (cf. Rom. 1:28) (Garland 2003:100-1).

56 From Danker (2000:953) three lexicographical possibilities exist: (a) to bring things together so as to

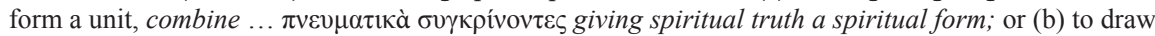
a conclusion by comparing, compare (1 Cor 2:13, may also be classified here: comparing the spiritual gifts and revelations (which we already possess) with the spiritual gifts and revelations (which we are to receive, and judging them thereby); or (c) to clarify on the basis of a compatible relationship, explain, interpret (interpreting spiritual truths to those who possess the Spirit, 1 Cor 2:13).

57 Already in 4.3 I have pointed out that the concluding phrase of this verse $\pi v \varepsilon v \mu \alpha \tau$.

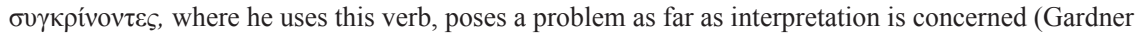
1994:138). The discussion of the problem and its solution have already been dealt with under section 4.3.

58 It is a compound that signifies "looking through a series (åvó) of objects or particulars to distinguish

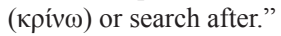

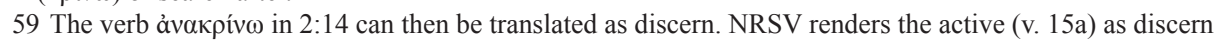
and the passive (v. 15b) as are themselves subject to scrutiny; the NIV (and approximately REB) makes judgments and subject to any man's judgment; NJB has assess and be assessed. In lexicographical terms

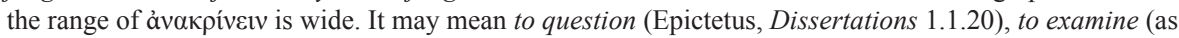
in examine the scriptures, Acts 17:11); to scrutinise or to judge, to assess, to put on trial (1 Cor 4:3-4; cf. 9:3; 1 Cor 9:3): to conduct an examination (Acts 12:19) (Thiselton 2000:273). 


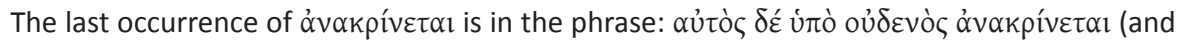
they are themselves subject to no one else's scrutiny, 2:15); there was certainly a difference in the way in which Paul and certain Corinthians understood this expression. For some Corinthians, this phrase signified a certain immunity or invulnerability from correction or critique. For Paul, however, it signifies at the very least that there are depths and dimensions to life in the Spirit that the person who lives on an entirely human level (v. 14) simply cannot comprehend. Aspects of Christian existence remain an enigma, unless others share the same insight as given by the Spirit of God.

Kaiser (1981:301-19) adds a supplementary perspective in his interpretation of "discernment" (ớ $\alpha$ kível) in 2:15. He includes "scripture". 60 He continues: "For the believer, the Scriptures are a light on his path and a lamp before his feet (Ps 119:105). He knows that in God's light he sees light (Ps 26:9).... He is able to distinguish truth from error ... and authenticity from pretence." Today correct discernment of the wisdom of God is also only to be enabled by the Spirit to those who are spiritual, not only by way of inductive impressions, but also through the deductive activities of imaginative exegesis. ${ }^{61}$ The activity of the Holy Spirit must not be confused. His work does not offer the spiritual person a short route that avoids grammatical, syntactical, historical, cultural, and theological exegesis. There is no highway in interpreting the Scriptures and to perceive the wisdom of God. The Spirit does not inculcate a meaning or meanings beyond what He has already taught biblical authors when they combined spiritual truths with the appropriately taught spiritual words. However, on the other hand, the Spirit of God does, and indeed must, aid the spiritual Christian in assessing, appraising, and evaluating the word, value, application, and significance of a biblical truth with the reader's need, personal condition and cultural conventions. No wonder, then, that Paul asserts that the spiritual man assesses

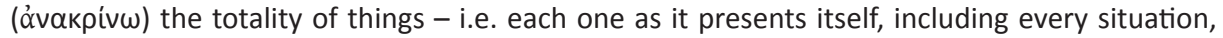
circumstance, and person he meets (Kaiser 1981:319). Using the above reasoning, the following diagrams, which I refer to as "the triangles of spirituality", 62 can be constructed for good sense. ${ }^{63}$

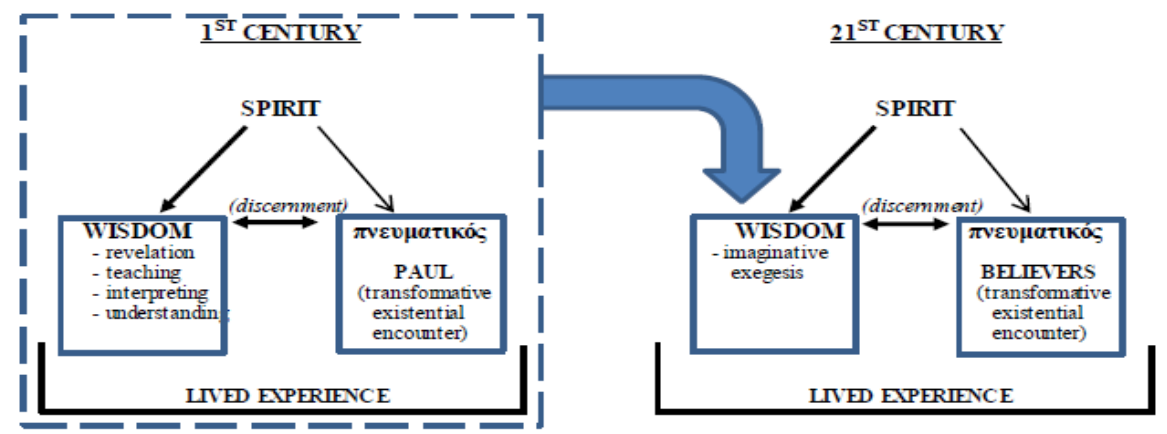

60 The chief hermeneutic (interpreting principle) is that the Bible interprets the Bible.

61 Lombaard's (2008:139-153; cf. also Schneiders 2002:137ff) use of this phrase "imaginative exegesis" is very descriptive in terms of what really happens or should happen in doing exegesis.

62 These triangles are referred to as "spiritual triangles" because the event encapsulated in this diagram has a spiritual effect. Each triangle reflects a spiritual event which was caused by the Spirit and experienced by a spiritual person.

63 I got this basic idea from Lombaard (2008:139-153), but adapted it to the reasoning of this paper. 
According to the "1st century" diagram, the Spirit communicates the wisdom of God to Paul (who is already spiritual, $\pi v \varepsilon \cup \mu \alpha \tau \imath \kappa o s)$ via revelation, teaching, interpretation and understanding (see 4.3). Paul's discernment of this wisdom of God creates within him a lived experience of a transformative existential encounter. Those who were spiritual in Corinth would also have experienced a transformative existential encounter when Paul communicated this wisdom to them. According to the "21st century" diagram, the Spirit also gives wisdom to spiritual persons through imaginative exegesis. ${ }^{64}$ Their discernment of this wisdom of God also creates a lived experience of transformative existential encounters within them. ${ }^{65}$ The first century "lived experience" of Paul creates a new lived experience in the lives of spiritual people today when they study Paul. In the $21^{\text {st }}$ century the role and task of exegesis also contributes to the "revelation, teaching, interpretation and understanding" of divine wisdom.

The isolation of cultural and historical antiquities should not excuse the interpreter (spiritual person) from searching for their meaning and contemporary significance for the church. To dismiss all such material, on the basis that it is totally outdated, allows cultural and historical contextualisation to triumph. This will cause the obstruction of the concerns of the literary context in which those phenomena are found (Kaiser 1981:305).

To summarise: it is evident from 1 Corinthians 2 that Paul discerned "Jesus Christ, and Him as crucified" as the essence of the wisdom of God, the wisdom that was revealed through and taught by the Spirit of God to him (i.e. Paul) personally. He understood such an event of discernment as that "spiritual truths ( $\pi v \varepsilon \cup \mu \alpha \tau \imath k \alpha \dot{)})$ came through spiritual expression taught by the Spirit who

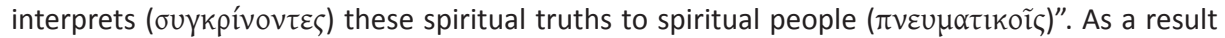
of this, Paul is convinced that the spiritual person can discern all things and therefore cannot be

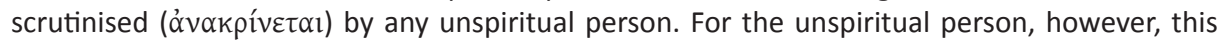
wisdom does not make any sense. For such a person the message of the cross is foolishness (1:8,

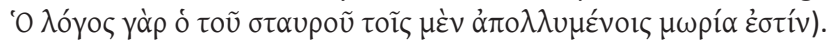

\section{CONCLUSION}

For Paul three constituents are required to discern the exclusive divine wisdom: the Spirit of God ( $\tau$ ov $\pi \nu \varepsilon v ́ \mu \alpha \tau o \zeta ~ \tau o \tilde{v} \theta \varepsilon o \tilde{)}$ ) who is the only one who can communicate it, a spiritual person $(\pi v \varepsilon \cup \mu \alpha \tau t k o ̀ \zeta)^{66}$ who is the only one who can receive and accept it and spiritual discernment

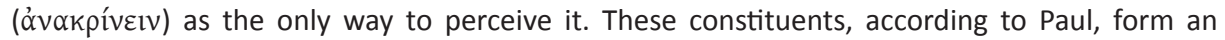
interwoven network that has to be considered holistically if we are to really understand his epistemology of discernment as described in the context of 1 Corinthians 2 . In this research the coherence and close relatedness of these constituents have been pointed out. ${ }^{67}$ The divine wisdom is, by its very nature, exclusive. Therefore, it can only be communicated by the Spirit of God. Paul negates the human involvement in the communication and discernment of the "wisdom of God." This again requires a spiritual level before anyone can discern ${ }^{68}$ this divine wisdom. According to Paul, the crucifixion and resurrection of Jesus (with practical related implications, 3:1-4) form the nucleus of this wisdom. Here it entails ultimately the soteriologicaleschatological renewal of nothing less than the entire creation (2 Cor 5:17). For the natural person, one without the Spirit of God, however, this wisdom does not make any sense. For such

64 Exegesis can include "Scripture," "tradition" as well as "circumstances."

65 See Schneiders (2002:139-141) on lectio divina.

66 In a second article I will investigate the nature of the spiritual person.

67 See also last diagram.

68 A second article will investigate how spiritual maturity is related to spiritual discernment: spiritual maturity the matrix for the discernment of the wisdom of God (an exploration in Pauline discernment: part 2). 
a person the message of the cross is foolishness.

During the first century, this discernment was not only based on pure knowledge (oĩ $\delta \alpha$ ), but also on acquired knowledge ( $\gamma \imath \omega \omega \sigma k \omega)$. Today, such acquired knowledge is still needed before anyone can discern the wisdom that God communicates to the church through his Spirit.

\section{BIBLIOGRAPHY}

Baird, W. 1959. Among the Mature. The idea of wisdom in 1 Corinthians 2:6. Interpretation 13 (4), 425-432. Balz, H R. \& Schneider, G. 1990. Exegetical dictionary of the New Testament (Vol. 1). Grand Rapids:

Eerdmans.

Barrett, C.K. 1992 [1964]. Christianity at Corinth. Manchester: John Rylands Library.

Brümmer, V. 1981. Theology and Philosophical inquiry. London: MacMillan.

-2005. Atonement, Christology and the Trinity, Making sense of Christian doctrine. Burlington: Ashgate.

-2006. Brümmer on meaning and the Christian faith. Burlington: Ashgate.

-2008. What are we doing when we pray? On prayer and the nature of faith. Burlington: Ashgate.

Büchsel, F. 1979. Koívw. In G. Kittel (ed.) TDNT (Vol. III). Grand Rapids: Eerdmans, 933-954.

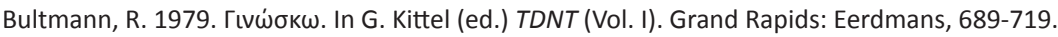

Cousar, C.B. 1990. 1 Corinthians 2:1-13. Interpretation 44 (2), 169-173.

Danker, W.F. 2000. Greek English Lexicon of the New Testament and other Early Christian Literature [ed., $3^{\text {rd }}$

Edition BDAG]. Chicago: University of Chicago Press.

Delling, G. 1978. દ̇pauvów. In G. Kittel (ed.) TDNT (Vol. II). Grand Rapids: Eerdmans,

655-57.

Dunn, J.D.G. 1995. 1 Corinthians. Sheffield: Sheffield Academic Press.

Du Plessis, P.J. 1959. TEAEIOE: The Idea of Perfection in the New Testament. Kampen: Kok.

Ellingworth, P. \& Hatton, H. 1995. A handbook on Paul's first letter to the Corinthians (UBS handbook series). New York: United Bible Societies.

Ellis, E.E. 1974 . "Wisdom" and "knowledge" in I Corinthians. Tyndale Bulletin 25, 82-98.

Fee, G.D. 1987. The First Epistle to the Corinthians. New International Commentary on the New Testament. Grand Rapids: Eerdmans.

Friberg, T., Friberg, B. \& Miller, N.F. 2000. Analytical lexicon of the Greek New Testament (Baker's Greek New Testament library, Vol. 4). Grand Rapids: Baker Books.

Gaffin, R.B. 1995. "Some Epistological Reflections on 1 Cor 2:6-16." Westminster Theological Journal 57, 103-24.

Garland, D.E. 2003. 1 Corinthians (Baker exegetical commentary on the New Testament). Grand Rapids: Baker Academic.

Gärtner, B.E. 1967-68. "The Pauline and Johannine Idea of 'to Know God' against the Hellenistic Background: The Greek Philosophical Principle 'Like by Like' in Paul and John." New Testament Studies 14, 209-231.

Gooch, P.W. 1987. Partial knowledge: philosophical studies in Paul. Notre Dame: University of Notre Dame Press.

Grindheim, S. 2002. "Wisdom for the Perfect: Paul's Challenge to the Corinthian Church (1 Corinthians 2:616)." Journal of Biblical Literature 121, 689-709.

Hartman, L. 1974. "Some Remarks on 1 Cor. 2:1-5." Svensk exegetisk årsbok 39, 109-120.

Herntrich, V. 1979. Kpívw. In G. Kittel (ed.) TDNT (Vol. III). Grand Rapids: Eerdmans, 921-933.

Horsley, R.A. 1977. Wisdom of word and words of wisdom in Corinth. CBQ 39 (2), 224-239.

Hurd, J.C. 1983. The origin of 1 Corinthians. New York: Seabury.

Kaiser, W. 1981. A neglected text in bibliology discussions: 1 Corinthians 2:6-16. Westminster Theological Journal 43 (2), 301-319.

Kistemaker, S.J. \& Hendriksen, W.2001. New Testament commentary: Exposition of the First Epistle to the Corinthians (New Testament Commentary, Vol. 18). Grand Rapids: Baker Book House.

Lim, T.H. 1987. "Not in persuasive words of wisdom, but in the demonstration of the Spirit and power." Novum Testamentum 29 (2), 137-149.

Louw, J.P. \& Nida, E.A. 1996. Greek-English lexicon of the New Testament: Based on semantic domains (electronic ed. of the 2 nd ed.). New York: United Bible Societies. 
Miller, G. 1972. Archontōn tou aiōnos toutou: a new look at 1 Corinthians 2:6-8. Journal of Biblical Literature 91 (4), 522-528.

Mitchell, S. 1991:87. Anatolia: Land, Men, and Gods in Asia Minor. Oxford: Clarendon Press.

Pogoloff, S.M. 1992. Logos and Sophia: The Rhetorical Structure of 1 Corinthians (Society of Biblical Literature, Dissertation Series 134). Atlanta: Scholars Press.

Polhill, J.B. 1983. The wisdom of God and factionalism: 1 Corinthians 1-4. Review \& Expositor 80 (3), 325339.

Pratt, R.L. (Jr.). 2000. I \& // Corinthians (Holman New Testament Commentary, Vol. 7). Nashville: Broadman \& Holman Publishers.

Prime, D. 2005. Opening up 1 Corinthians. Leominister: Day One Publications.

Rhyne, C.T. 1990. 1 Corinthians 3:1-9. Interpretation 44 (2), 184-179.

Schlier, H. 1979. Bá日oc. In G. Kittel (ed.) TDNT (Vol. I). Grand Rapids: Eerdmans, 517-518.

Schnelle, U. 2005. Apostle Paul. His life and theology (transl. By M.E. Boring). Grand Rapids: Baker Academic.

Schrage, W. 1991. Der erste Brief an die Korinther (1 Kor 1,1-6,11) (Evangelisch-katholischer Kommentar zum Neuen Testament 7/1). Zurich: Benziger/Neukirchen-Vluyn: Neukirchener Verlag.

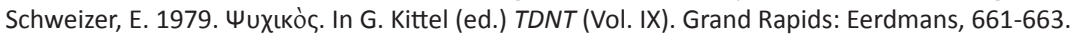

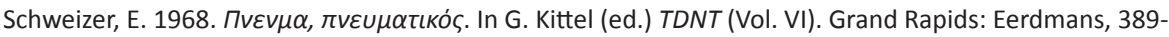
455.

Schmitz, E.D. 1976. Knowledge. In C. Brown (ed.) DNTT (Vol. II). Exeter: Paternoster Press., 390-406.

Stuhlmacher, P. 1987. The Hermeneutical significance of 1 Corinthians 2:16-16. In G.F. Hawthorne (ed.) Tradition and Interpretation in the New Testament: essays in honor of E. Earle Ellis for his 60th birthday, Grand Rapids: Eerdmans, 330-332.

Swanson, J. 1997. Dictionary of Biblical Languages with Semantic Domains: Greek (New Testament) (electronic ed.). Oak Harbor: Logos Research Systems.

Theissen, G. 1987. Psychological aspects of Pauline theology (Transl. by J.P. Galvin). Philadelphia: Fortress Press.

Thiselton, A.C. 2000. The First Epistle to the Corinthians: A Commentary on the Greek Text (New International Greek Testament Commentary). Grand Rapids: Eerdmans.

Waaijman, K. 2002. Spirituality. Forms, foundations, methods. Leuven: Peeters.

Zodhiates, S. 2000. The complete word study dictionary: New Testament (electronic ed.).

Chattanooga: AMG Publishers.

\section{KEY WORDS}

Literary context

Discerment

Wisdom of God

Spirit of God

Spiritual person

\section{TREFWOORDE}

Literêre konteks

Beoordeel/besluit

Wysheid van God

Gees van God

Geestelike mens 